ENCYCLOPEDDIE Encyclopédie berbère

BERBERE

1 | 1984

1 | Abadir - Acridophagie

Abū l'Khattab ben 'Abd al-'Ala

(Voir Ibadites)

G. Camps

\title{
OpenEdition
}

Journals

Édition électronique

URL : http://journals.openedition.org/encyclopedieberbere/799

DOI : $10.4000 /$ encyclopedieberbere.799

ISSN : 2262-7197

Éditeur

Peeters Publishers

Édition imprimée

Date de publication : 1 novembre 1984

Pagination : 91

ISBN : 2-85744-201-7

ISSN : $1015-7344$

Référence électronique

G. Camps, «Abū I'Khattab ben 'Abd al-'Ala », Encyclopédie berbère [En ligne], 1 | 1984, document A28, mis en ligne le 01 décembre 2012, consulté le 05 octobre 2020. URL : http://journals.openedition.org/ encyclopedieberbere/799; DOI : https://doi.org/10.4000/encyclopedieberbere.799

Ce document a été généré automatiquement le 5 octobre 2020.

(c) Tous droits réservés 


\section{Abū l'Khattab ben 'Abd al-'Ala}

\section{(Voir Ibadites)}

\section{G. Camps}

1 Premier imam des Ibadites du Jbel Nefoussa. Il fut élu à Siad, près de Tripoli, en 757-758 et s'empara de Tripoli puis il marcha contre les Warffajjūma, berbères kharedjites de la secte sofrite qui, maîtres de Kairouan, y commettaient des excès sans nom et d'horribles massacres. Il soumit Gabès puis assiégea la ville sainte. Kairouan fut emportée en juillet 758. Pendant quelques années Abū l'Khattab fut maître de toute l'Ifrīqiya. Les armées abbassides envoyées contre lui par le gouverneur d'Égypte furent par deux fois battues avant même d'atteindre la Tripolitaine, mais une troisième, commandée par Ibn al-Aš‘at, réussit à tromper la vigilance d'Abū l'Khattab qui fut battu et tué à Tawurgha en juin 761.

\section{BIBLIOGRAPHIE}

Voir Ibadites.

ABŪ ZAKARYA EL-WARGALANi. Chronique. Trad. de R. Le Tourneau in Rev. africaine, t. 104, 1960, p. 99-176 et 322-390.

BASSET R. Les sanctuaires du Djebel Nefoussa, Paris, 1899.

\section{INDEX}

Mots-clés : Biographie, Libye, Moyen Âge 